\title{
The University of Toronto Health Service, Oral Contraception, and Student Demand for Birth Control, 1960-1970 ${ }^{1}$
}

\section{Christabelle Sethna}

The birth control pill is routinely associated with the so-called sexual revolution of the 1960s. Yet this case study of the impact of the pill on the University of Toronto, reveals that young, single, white, middle-class women students were not always able to access this prescription contraceptive at the campus Health Service. The refusal or reluctance of the Health Service to prescribe the pill to single women students resulted in heightened male and female student pressure on the Health Service to do so. The development of and changes to the Health Service's policy on the provision of oral contraceptives to single women students reflected the often contradictory moral, legal and administrative positionalities of that Service. The result was a complex dynamic marked by conflict and collusion.

La pilule contraceptive est communément associée à la dénommée révolution sexuelle des années 1960 . Pourtant, cette étude de cas de l’impact de la pilule à l'Université de Toronto révèle que les jeunes étudiantes célibataires blanches de la classe moyenne n'étaient pas toujours capables d'obtenir ce médicament sous ordonnance auprès du Service de santé du campus. Le refus ou la répugnance du Service de santé à prescrire la pilule à des étudiantes célibataires eurent pour résultat d'intensifier la pression des étudiants et des étudiantes en faveur de sa disponibilité. Le développement et les changements apportés à la politique du Service de santé à l'égard de l'approvisionnement des étudiantes célibataires en contraceptifs oraux reflétèrent les prises de position morales, légales et administratives souvent contradictoires de ce Service. Il s’ensuivit une dynamique complexe marquée par le conflit et la collusion.

On February 15, 1967, the Varsity, the main student newspaper for the University of Toronto ( $U$ of T), published an angry letter from undergraduate student Jim Sayers. A furious Sayers denounced Dr.

1 I thank Steve Hewitt, Mary Bird, Harold Averill, Mary Auxi Guiao, Charles Levi, and Jane Wodehouse for their assistance. Steven Maynard and two anonymous reviewers for HSE provided insightful commentary. I am grateful to the Faculty of Education, University of Ottawa, and to the Social Sciences and Humanities Research Council of Canada for funds provided to hire research assistants Amélie Chrétien, Adinne Schwartz, and Corrie Level. Versions of this paper have been presented at the Annual Meeting of the Canadian Historical Association, University of Toronto, Toronto, May 27-29, 2002, and at the International Federation for Research on Women's History, Queen's University, Belfast, Ireland, August 11-14, 2003. 
George E. Wodehouse, Director of the campus Health Service, for prescribing "celibacy and avoidance" instead of the birth control pill to single women students. "I wish the members of the otherwise inadequate Health Service would keep their personal convictions from interfering with the function of the Service," Sayers frothed, "[t]o Dr. Wodehouse, and to those who may have a knife at his back, I say... give the pill to those who want it, and see if the sky falls down. I'm sure it won't." Taking a final swipe, he demanded: "how long will a pluralist campus tolerate such a naive, neo Puritan, self-righteous, not to mention totalitarian attitude?"2

In the 1960s, a so-called sexual revolution that sanctioned premarital sex for young, white, single, middle-class women coincided with the introduction of the birth control pill, thereby motivating campus Health Services to consider the provision of the pill to unmarried female students. ${ }^{3}$ Unfortunately, published accounts that trace the impact of oral contraceptives on campus are sparse and often cursory. Lara V. Marks credits university Health Services in Britain as the first place where many educated, single women first came into contact with the pill. ${ }^{4}$ Doug Owram posits that Health Services at many Canadian universities quietly provided oral contraceptives to single women students. ${ }^{5}$ American historian Beth Bailey tells a far more complex tale of the pill at one Midwestern university community. Recognizing that medical doctors controlled access to the pill by prescription, Bailey suggests that one cannot blithely assume that the pill suddenly became available to the very women who were considered icons of the sexual revolution. Rather, the pill was fought over and fought for. ${ }^{6}$

In this preliminary case study of the $\mathrm{U}$ of $\mathrm{T}$, I chart the on-campus struggle that the university's Health Service and the student population waged over the pill. I argue that the refusal or reluctance of the Health Service to prescribe the pill to single women students resulted in heightened student pressure on the Health Service to do so. The

2 Jim Sayers, "Give the pill to those who want it," Varsity, Feb. 15, 1967, p. 4.

3 F.K. Harding, "The College Unmarried Population Explosion," Journal of School Health 35, 10 (Dec. 1965): 450-57; Willard Dalrymple, "A Doctor Speaks of College Students and Sex," Journal of the American College Health Association (JACHA) 15, 3 (Feb. 1967): 279-86; Emanuel Klein, "The Need for Family Planning as a Student Health Service,” ibid., 16, 1 (Oct. 1967): 95-98; Ethel M. Nash, “The College Physician's Role in Sex Education,” ibid., 15: Supplement (May 1967): 66-71; "Contraceptives for Students: An Invitational Symposium," Journal of Reproductive Medicine 4, 2 (Feb. 1970): 9-18.

4 Lara V. Marks, Sexual Chemistry: A History of the Contraceptive Pill (New Haven and London: Yale University Press, 2001), 106-7. See also Ira L. Reiss, The Social Context of Premarital Sexual Permissiveness (New York: Holt, Rinehart, and Winston, 1967).

5 Doug Owram, Born At the Right Time: A History of the Baby Boom Generation (Toronto: University of Toronto Press, 1996), 267-69.

6 Beth Bailey, "Prescribing the Pill: Politics, Culture, and the Sexual Revolution in America's Heartland," Journal of Social History 30, 4 (Summer 1997): 827-56. 
development of and changes to the Health Service's policy on the provision of oral contraceptives to single women students reflected the often contradictory moral, legal, and administrative positions of that Service. Students, both male and female, tapped into shifting and interconnected political discourses that ranged from student power to population control to women's liberation in order to liberalize the Health Service's policy on pill prescriptions. However, Health Service personnel, individual students, and various student factions were not always at odds with each other. Rather, their interaction can be characterized more correctly as one of conflict, collusion, and co-optation.

\section{The U of T Health Service}

Established in 1906, the Health Service's main concern initially was to keep the student body free from exposure to infectious diseases like tuberculosis. As the student population swelled with returning servicemen after the end of the Second World War, the Health Service expanded rapidly. Despite cramped conditions, it came to include separate facilities for men and women, a clinical consulting service, a psychiatric service, an athletic injury service, and an infirmary. It even offered a screening program for parasitic infections and tropical diseases for students travelling to and from Afro-Asian countries. An Advisory Committee to the Health Service, chaired by the Dean of the Faculty of Medicine, was composed of senior representatives from various departments within the Faculty of Medicine, as well as the Chairman and the President of the university, ex officio. The Advisory Committee met annually but the Health Service Director met more frequently with the Dean of the Faculty of Medicine in regard to the Health Service. Wodehouse became Health Service Director in 1950 and retired in 1984. Dr. Frances Stewart, a physician employed at the Health Service before the war, was the Health Service's Assistant Director and the Head of the Women's Division between 1946 and 1976. Both Wodehouse and Stewart had served in the armed forces during the war, making them a generation older than the student clientele of the 1960s. ${ }^{7}$

During this decade the enrolment of male and female students in universities increased considerably. ${ }^{8}$ With this demographic surge, the

$7 \quad$ University of Toronto Archives (UTA), A83-0036, Box 34, File: University Health Service (UHS), "University Health Service: University of Toronto," pp. 1- 27, June 1976, and Health Service Records, "Minutes of the Advisory Committee to the University Health Service,” Sept. 14, 1965, p. 1. Existing records of the Health Service are meagre; the most rewarding primary sources are the minutes of the Advisory Committee. Both Wodehouse and Stewart are now deceased. Neither, to my knowledge, left private papers on deposit.

8 Dominion Bureau of Statistics, Education in Canada: A Statistical Review for the Period 1960-61 to1970-71 (Ottawa: Statistics Canada, 1973), 58. 
Health Service experienced a 20 per cent rise in total utilization and a 24 per cent jump in its office consultations. Wodehouse was quick to assert that the statistics did not indicate that more students were unwell. Rather, they reflected two trends. The first was students' growing acceptance of the Health Service as their primary health care option. The second was, as he put it, "student interest in sex education and contraceptive education and prescription." 9 The word "prescription" was a master stroke of linguistic subtlety. It allowed the ever-discrete Wodehouse to refer indirectly to heightened student demands that the Health Service prescribe oral contraceptives to single women students. Tuberculosis had obviously taken a back seat.

\section{Sex and Birth Control in Canada}

Scholars have shown that before the 1940s, heterosexual courtship among white, middle-class youths was a competitive system that encouraged individuals to date different partners. After 1945, in keeping with the Cold War quest for national security, dating patterns changed. ${ }^{10}$ Couples went steady, dating one individual regularly, often until marriage. Despite the widespread acknowledgement of necking and petting activity in steady relationships, young women were required, however, to safeguard their virginity. ${ }^{11}$.However, unintended pregnancies increased after 1945 in single women younger than 20 years of age. A drop in the mean age of menarche and in marriage rates after 1951 for females aged 15 to 19 contributed to this trend. ${ }^{12}$

Early in the 1960s the term "sexual revolution" was used to indicate the "suspected impact" of the birth control pill on the sexual behaviour of female students in institutions of higher education. ${ }^{13}$ Whether premarital sexual behaviour in young, white, middle-class women actually changed significantly during the decade remains the subject of

9 G. E. Wodehouse, "The Director of the University Health Service," University of Toronto, President's Report 1965-1966, 218.

10 Elaine Tyler May, Homeward Bound: American Families in the Cold War Era (USA: Basic Books, 1988).

11 See Beth L. Bailey, From Front Porch to Back Seat: Courtship in TwentiethCentury America (Baltimore and London: The Johns Hopkins University Press, 1989 [1988]).

12 Christabelle Sethna, "WE WANT FACTS NOT MORALS!" Unwanted Pregnancy, the Toronto Women's Caucus and Sex Education," in Ontario Since Confederation: A Reader, ed. Edgar-André Montigny and Lori Chambers (Toronto: University of Toronto Press, 2000), 410.

13 David Allyn, Make Love, Not War: The Sexual Revolution: An Unfettered History (New York: Routledge, 2001), 4. 
debate. ${ }^{14}$ What is clear is that at least in the United States, race was a key variable in research on female sexuality. American data apparently showed that young, single, white women living at home or in college dormitories were having heterosexual intercourse more frequently and with more sexual partners than those in their black cohort. ${ }^{15}$ Similar Canadian studies were few. Investigators were more likely to use geographic, economic, linguistic, and/or religious rather than racial indicators. Like their American counterparts, Canadians claimed to have detected a "massive increase" in single females reporting sexual intercourse, especially in the Anglophone, urban university population. ${ }^{16}$ Because Canada's Indigenous population was marginalized, and because the country had yet to experience a wave of immigration from Third World countries, it can be safely assumed that the vast majority of the students surveyed in Canadian educational institutions were white. ${ }^{17}$

Additional research showed that because of the direct relationship between coital experience and age, a sizable proportion of males and females would have intercourse for the first time while at university. ${ }^{18}$ Surveys of this group's sexual activity revealed that approximately 28 per cent of males and females engaged in heavy petting on dates. Of the males, 22 per cent admitted to having had sexual intercourse while nearly 15 per cent of females did. However, 15 per cent of females and almost the same percentage of males admitted not having any knowledge of contraceptives. Sex education in schools was spotty. A 1964 survey showed not one of 55 urban school systems taught family life education as a separate subject. For 35 of the respondents, sex education was included in subjects like home economics and social sciences. Contraception was rarely discussed as a topic. It was not surprising that

14 For a summary of various arguments for and against the periodization of the sexual revolution of the 1960s, see Alan Petigny, "Illegitimacy, Postwar Psychology, and the Periodizaton of the Sexual Revolution,” Journal of Social History 38, 1 (Fall 2004): 6380. See also Ira L. Reiss, The Social Context of Premarital Sexual Experience (New York: Holt, Rinehart and Winston, 1967).

15 For example, see John F. Kantner and Melvin Zelnick, "Sexual Experiences of Young Unmarried Women in the United States," Family Planning Perspectives 4, 4 (Oct. 1972): 9-18.

16 Charles W. Hobart, "Sexual Permissiveness in Young English and French Canadians," Journal of Marriage and the Family 34, 2 (May 1972): 302, and W. E. Mann, "Canadian Trends in Premarital Behaviour: Some Preliminary Studies of Youth in High School and University,” Bulletin: The Council for Social Service (Dec. 1967): 163.

17 See Frances Henry, Carol Tator, Winston Mattis, and Tim Rees, The Colour of Democracy: Racism in Canadian Society, $2^{\text {nd }}$ ed. (Toronto: Harcourt Canada, 2000), 8188.

18 F. Michael Barrett, "Sexual Experience, Birth Control Usage, and Sex Education of Unmarried Canadian University Students: Changes Between 1968 and 1978," Archives of Sexual Behavior 9, 5 (1980): 385. 
by the mid-sixties, one-third of the 26,000 unwed mothers in Canada were reported to be teenagers. ${ }^{19}$

Youths' ignorance of contraception was fuelled by the fact that birth control was illegal in Canada. From the late nineteenth century onward, the Criminal Code prohibited abortion as well as the sale, advertisement and dissemination of contraception. A few birth control clinics influenced by the eugenics movement dispensed contraceptives to poor married women from the 1920s on. The courts determined in the 1930s that birth control was permissible if in the public good. Nevertheless, in the early 1960s, a Toronto pharmacist was convicted of selling condoms through the mail. Canada's birth control laws also had a negative effect on the country's performance at the United Nations. Canadian delegates could not officially support UN family planning initiatives abroad because birth control was still illegal at home. ${ }^{20}$ Abortion, whether self-induced or performed by medical or non-medical personnel, remained an underground secret practice. Between 1962 and 1966, abortion was the main cause of maternal deaths in some provinces like Ontario. ${ }^{21}$

The federal government approved the oral contraceptive pill on a doctor's prescription in 1961 . The pill, which offered nearly 100 per cent protection against conception, had the potential to free married and single women from unintended pregnancy. But oral contraception was very much a Cold War spawn, intended for specific populations. On the international scene, the pill was recommended as a means of curbing population increases in Asia and Africa. Nationally, the pill was advocated as a fertility control measure for the same minority groups the poor and the Aboriginal - that had been targeted by the eugenics movement for sterilization. However, oral contraception was earmarked for married women, or for women engaged to be married, for their family planning goals. $^{22}$

When it came to prescribing the pill to single women, physicians, in general, were torn by moral and legal considerations. Some refused to prescribe the pill because they were against premarital sex or because

19 William Edward Mann, Canadian Trends in Premarital Behaviour: Some Preliminary Studies of Youth in High School and University (Toronto: The Council for Social Service, 1967), 24-29; Elise Jones et al., Teenage Pregnancy in Industrialized Countries (New Haven and London: Yale University Press, 1986), 82; Canadian Education Association, The Present Status of Sex Education in Canadian Schools, Report No. 2, September, 1964 and Sethna, "WE WANT FACTS NOT MORALS!” 410.

20 Angus McLaren and Arlene Tigar McLaren, The Bedroom and the State: The Changing Practices and Politics of Contraception and Abortion in Canada, 1880-1997, 2d. ed. (Toronto: Oxford University Press, 1997).

21 Robin F. Badgley, Marion Powell and Denyse Fortin Caron, Report of the Committee on the Operation of the Abortion Law (Ottawa: Minister of Supply and Services, 1977), 66.

22 Christabelle Sethna, "A Bitter Pill," in Canada: Confederation to the Present, ed. Bob Hesketh and Chris Hackett (Edmonton, Alberta: Chinook Multimedia, Inc., 2001); http://chinookmultimedia.com/poccd/registered/web_papers/case_studies5.php 
they were afraid of being viewed as promoting sexual promiscuity. Others were concerned that they could face criminal suits for dispensing contraceptives. The treatment of minors who fell below provincial age limits for consent to medical care was another legal grey area. It was speculated that without parental notification, the gynaecological examination often required for a pill prescription and the pill prescription itself could lead technically to charges of battery or to contributing to the delinquency of a minor. ${ }^{23}$ It was not surprising, therefore, that young women were often reluctant to approach a family physician to discuss their contraceptive needs for fear of being rejected. ${ }^{24}$

\section{The U of T Health Service Policy on Contraceptive Prescription}

Experts held university students to be vulnerable to stress not only because of their new living arrangements, financial difficulties, study preparation, and career prospects but also because of pressures relating to sexuality. ${ }^{25}$ Yet some critics accused institutions of higher learning of being "a timid, cloistered collection of scholars who would like sex to disappear into a test tube which could be forever stoppered, sealed and buried deep into the earth." ${ }^{\text {} 26}$ There was no doubt, however, that the moral and legal considerations of prescribing the pill to single women were compounded for university Health Services. Some Health Service doctors dismissed student requests for contraception, complaining that they required "counselling and mental discipline," not "more permissiveness in the form of the 'pill'.,"27 Nevertheless, many doctors at Health Services, especially those who held faculty appointments, felt compromised by the possibility of public exposure. ${ }^{28}$

Universities, in their role of guardian, in loco parentis, feared the negative reaction of parents and government officials. ${ }^{29}$ Moreover, Health Services were confused over their function in relation to a sexually active

23 See Martin G. Wolfish, "Birth control counselling in an adolescent clinic," Canadian Medical Association Journal 105, 7 (Oct. 9, 1971): 750; Walton Prescott, "A College Health Service Should Not Dispense Birth Control Devices and Medications," JACHA 16, 3 (Feb. 1968): 240-43, and Henri Major, Notes on the Law of Birth Planning in Canada (Ottawa: Canadian Advisory Council on the Status of Women, 1975), 5-7.

24 Paul Sachdev, "Canadian Research in Family Planning: Its Implications for Social Work," in Family Planning and Social Work (Ottawa: Ministry of National Health and Welfare, 1976), 544-45.

25 World Health Organization, University Health Services: Fourteenth Report of the WHO Expert Committee on Professional and Technical Education of Medical and Auxiliary Personnel (Geneva 1966), 4.

26 Alan F. Guttmacher and Eugene E. Vades, "Sex on the Campus and the College Health Service," JACHA 21, 2 (Dec. 1972): 145.

27 Prescott, "A College Health Service Should Not," 241 and 242.

28 Maurice M. Osborne, Jr., "A College Health Service Should Dispense Birth Control Information, Services and Medications," JACHA 16, 3 (Feb. 1968): 235-50.

29 Owram, Born at the Right Time, 268. 
student population. ${ }^{30}$ Few of the university Health Services polled in 1965 were willing to provide single women students with the pill. A survey of 323 Canadian and American institutional members of the American College Health Association (ACHA) revealed that more than 55 per cent of the respondents did not prescribe the pill for contraceptive purposes. Those campus Health Services that refused to prescribe the pill took the position that contraception was not their responsibility. Those campus Health Services that did, suggested, in a manner that anticipated prochoice statements regarding abortion, that pill prescriptions were a private matter between physician and patient. In total, 44 per cent of the respondents prescribed the pill for married students but 76 per cent reported that they would not prescribe the pill to any unmarried student. Ninety-six per cent claimed they would not prescribe the pill for any unmarried student under age 21 . Only slightly more than 8 per cent said that they prescribed the pill for women before their upcoming marriage. This shockingly low statistic was at odds with what was believed at the time to be the physiological action of the pill. It was then understood that for maximum contraceptive protection, the pill must be used for at least one complete menstrual cycle before unprotected sexual intercourse occurred. ${ }^{31}$

On September 14, 1965, Wodehouse, an active ACHA Council member, informed the Advisory Committee to the Health Service that there had been "widespread agitation by students in other centers for the provision of sex education, contraceptive information and education and contraceptive prescription.” In the United States, scandals concerning campus Health Services that had surreptitiously prescribed the pill to unmarried students were mushrooming in the popular and student press. ${ }^{32}$ Wodehouse warned that a similar situation was "imminent" at the U of $\mathrm{T} .{ }^{33}$ here was little reason to suspect otherwise. Given the direction of New Left politics, $U$ of $T$ students were already working to change the structure of society via direct action, individual human development, and participatory democracy. Sexual experimentation was viewed as an important part of the generational rebellion against the old order. ${ }^{34}$ Students charged that the university itself was a hypocritical institution

30 National Archives of Canada (NAC), RG33, Series 89, “A Report Prepared for the Royal Commission on the Status of Women on Behalf of the Council of Associations of University Student Personnel Services,” Brief 426, Aug. 1968, p. 17. My thanks to Tanya Middlebro for help with this reference.

31 "Dispensing of Birth Control Information, Devices and Medications in College Health Services: A Panel Discussion: Report of the Committee on Ethical and Professional Relationships," JACHA 16, 3 (Feb. 1968): 233-35. See also NAC, “A Report Prepared,” 17.

32 Allyn, Make Love, Not War, 38-39.

33 University Health Service, Minutes of the Advisory Committee to the University Health Service, Sept. 14, 1965, p. 3.

34 Beth Bailey, Sex in the Heartland (Cambridge, Mass., and London, England: Harvard University Press, 1999), 157. 
that took moral positions on students' drinking, drug taking, and sexual activity while enjoying immoral relationships with industries that promoted war, racism and weapons production. ${ }^{35}$ However, many politically active students believed that political change was impossible because the in loco parentis role of universities had infantilized students. It was only a matter of time until some students could claim that the same authoritarianism had also blocked their access to the pill. Student Marvin Ross expressed the tenor of the times when he commented that students were not to be treated as infants "to be suckled by Simcoe Hall." U of T students, he noted, were adults. They grew up very quickly when they realized that "not all middle class boys and girls should and do remain celibate until they are married." 36

Bolstered by national stability, an economic upturn and higher educational attainments, Canadians were increasingly expecting access to a comprehensive range of heath care services and better medical insurance. ${ }^{37}$ By Wodehouse's own admission, the U of T Health Service was becoming vital to students, each of whom was required to pay a small Health Service fee that accounted for 60 per cent of the Health Service's annual budget. He believed that although the $\mathrm{U}$ of $\mathrm{T}$ was located in a large city with numerous hospitals and physicians, it was relatively difficult to secure a family physician. For a student moving to Toronto or for one living on the city's outskirts, the task would be more difficult. Like any of the other services offered by the university, the Health Service maximized students' abilities to concentrate on their educational experience. Unlike other practitioners, Health Service personnel were well accustomed to dealing with the special problems of youth. Wodehouse reasoned that student need for the Health Service was sure to increase. Growing enrolment was not the only reason. Changes to the province's medical insurance system would make more health care services available to a larger number of students. ${ }^{38}$

To stave off possible criticism of the Health Service from students while balancing the concerns of Health Service staff, university administrators, government officials, and parents, the Advisory Committee took two important steps. First, it invited two students from the student government - the Students' Administrative Council (SAC) -

35 UTA, A1000-1984, A84-1046, Brief by D. J. McCulloch, Advisory Bureau, University of Toronto, July 1968, pp. 3-4. See also Owram, Born at the Right Time, 21647, and Martin Friedland, The University of Toronto: A History (Toronto: University of Toronto Press, 2002), 526-42.

36 Marvin Ross, "Students are treated like children," Varsity, Nov. 2, 1966, p. 5.

37 Royal Commission on Health Services, vol. 1 (1964), esp. 3-15 and 431-45.

38 UHS, Brief to M. Robin Ross by G. E. Wodehouse, "The Future of the University Health Service,” March 1968. For an overview of changes to Canadian health care in the 1960s, see J.E.F. Hastings, "Federal-Provincial Insurance for Hospital and Physician's Care in Canada," in Perspectives on Canadian Health and Social Services Policy: History and Emerging Trends, ed. Carl A. Meilicke and Janet L. Storch (Ann Arbor, Michigan: Health Administration Press, 1980), 198-219. 
to sit as representatives, and Robin Ross, U of T Registrar, Director of Student Services, and the person responsible for the Health Services budget, to sit as a new member. The invitation to the two students may have reflected the Advisory Council's responsiveness to student demands for student participation on university bodies. However, it is more likely that the invitation signalled the Advisory Committee's pragmatic desire to co-opt student concerns. Ross's membership may have been equally strategic. Regularly faced with student unrest in the wider university community, Ross distinguished student "activists" from student "revolutionaries.” To him, the former were intelligent, idealistic, and politically sensitive individuals who wanted to improve the university. The latter evoked "sorrow" because they called for the university's destruction. $^{39}$ Ross's experience dealing with both types of students could have been perceived as a major asset to the Advisory Committee.

Second, the Advisory Committee hammered out a formal Health Service policy on contraceptive prescriptions. Its members agreed that although Health Service staff could assist with educating students about birth control,

it would be an improper and unfitting policy at this time for the [Health] Service to provide indiscriminate contraceptive prescription. While it was recognized that contraceptive prescription will always remain a matter of individual medical judgement and decision, in general, at the University, such prescription should be limited at present to married students and to those students in their period of premarital counselling. ${ }^{40}$

Wodehouse would later claim that the policy was deliberately "indecisive" so as to permit physicians to meet some of the contraceptive needs of single women students. ${ }^{41}$ Ever discrete, he reported to the $\mathrm{U}$ of $\mathrm{T}$ President that although the Health Service continued to limit pill prescriptions to students who were married or engaged, "it seems likely that at least a number of other patients will continue to present themselves who will require individual medical judgement in the advice given." 42 The policy's loophole phrase "contraceptive prescription must always remain a matter of individual medical judgement and decision" - hinted at the autonomy of Health

39 Robin Ross, The Short Road Down: A University Changes (Toronto: University of Toronto Press, 1984), 95.

40 UHS, Minutes of the Advisory Committee to the University Health Service, Sept. 14, 1965, p. 3. See also Wodehouse, President's Report, 1965-1966, 218.

41 UTA, A75-0021, Box 103, File: Health Services, letter to J. H. Sword from G.E Wodehouse, Oct. 6, 1967, and letter to George Tatham from G.E. Wodehouse, Oct. 6, 1967.

42 G.E. Wodehouse, "The Director of the University Health Service," President's Report, 1966-1967, 236. 
Services doctors. Yet the physicians themselves were unsure of their position. Dr. David Smith, from the Men's Division of the Health Service, remembers prescribing the pill to any female student who happened to see him: "George [Wodehouse] had to be very careful. There were some terrible fuddy duddies at the University. But when kids came in, we gave it [the pill] to them." However, Dr. Ruth Davis in the Women's Division, tells a different story: "We wouldn't have prescribed the pill if it were illegal. George [Wodehouse] was very careful about the law."43

\section{Student Pressure on the Health Service}

Despite its best intentions, the Advisory Committee failed to prevent student agitation for birth control. On the one hand, the Advisory Committee's attempt at juggling the needs of students in regard to the other constituencies involved was nothing short of Herculean. On the other hand, student frustration with their respective Health Services was at a boil across Canada. The University of British Columbia (UBC) had already exploded in controversy over pill prescriptions. Ann Ratel, a single student and reporter for the student newspaper, the Ubyssey, borrowed a wedding ring, assumed a fictitious last name and presented herself to the Health Service at Wesbrook Hospital as a newly married woman. Her ruse worked. A Health Service doctor gave her a two-year prescription for Ortho-Novum. Under the cheeky front-page headline, "Our bachelor girl perforates leaky Wesbrook pill policy," the Ubyssey printed Ratel's prescription with the physician's signature mercifully blotted out. ${ }^{44}$

One of the earliest examples of student demands for birth control services occurred at U of T's University College Literary and Athletic Society. Known colloquially as "The Lit," the Society was founded in 1854. It was the oldest student union in Canada and publisher of the first issue of the Varsity, the U of T's main student newspaper, in 1880. At a December, 1965, meeting, Lit President Daniel Cooper proposed a bold motion to set up a student birth control program:

Since the Society considers the existing laws on birth control are unsuitable, and desires their ultimate change to suit present conditions, and since we believe that steps toward sex education should be taken, be it therefore moved that University College Literary and Athletic Society sponsor a programme of lectures and seminars on sex education and birth control; that the Lit try to secure

43 Personal telephone interview with Dr. David Smith, May 9, 2002, and with Dr. Ruth Davis, May 16, 2002.

44 Ann Ratel, "Un-Ortho-Dox: Our bachelor girl perforates leaky Wesbrook pill policy," Ubyssey, Sept. 30, 1965, p. 1. 
the support of the University Health Service and the college administration for such a programme; that after such a programme is held, the Lit assess the success of the programme and consider taking further steps. ${ }^{45}$

Lit members were aware that what they were proposing was illegal under the Canadian Criminal Code. That's why the motion asked for the support of the college administration and the Health Service. The Health Service, the students understood correctly, was technically breaking the law because it was already dispensing birth control information and devices to engaged and married students. The motion passed, but with heated discussion. Several members wanted the Lit to force a test case of the law. They proposed sending a married student to the Health Service to get birth control information and then demand that the Health Service be prosecuted. Others objected, claiming that a test case would only compromise whatever birth control services the Health Service was already providing. ${ }^{46}$ The Lit's next step was to seek SAC endorsement for their birth control program. Here the motion ran into trouble. A few SAC members asked to discuss the matter with their local councils. Others opposed the possibility of SAC approval for a program that was illegal. Still others did not wish SAC to support a program that originated at a specific college. An engineering student injected some humour into the debate, commenting that the birth control program was an "underhanded plot by UC [University College] to eventually decrease the number of engineers." 47 The motion, however, failed at SAC.

Although SAC did not initially stand behind the Lit's birth control program, support for the issue was growing. Up until the mid-1960s, SAC had functioned as a student government intent on providing students with social, cultural, and communications services. Still, early indications of SAC's radicalization were apparent. In 1959, because of an incident of racial discrimination at a women's sorority, SAC sponsored a lecture on "The Problem of Race Relations." ${ }^{48}$ A few years later, SAC President Jordan G. Sullivan cited Bissell's address to student leaders on campus - "you are deeply conscious of yourselves as citizens going into a world where you will be asked to share greater and greater responsibility" - to introduce some changes in direction. ${ }^{49}$ SAC was becoming more independent. It was sponsoring model Parliaments, decrying discrimination in student housing, and debating Canada's involvement in the nuclear arms race. During the 1965-1966 academic year, the Council

\footnotetext{
45 Student Administrative Council (SAC), SAC Statutes, 1966-1967, p. 4.

46 Volkmar Richter, "Lit plans sex lectures," Varsity, Dec. 8, 1965, p. 1.

47 Deanna Kamiel, "SAC postpones birth vote," Varsity, Dec. 10, 1965, p. 3.

48 E. A. Macdonald, "The General Secretary-Treasurer of the Students' Administrative Council," President's Report, 1960, 138.

49 Jordan G. Sullivan, "The President of the Students' Administrative Council," President's Report, 1965-1966, 170.
} 
"began to deal with the political issues that would dominate its discussions and activities throughout the ensuing decade."50

The two major issues on the table were the financing of higher education and student participation in university government. On the first point, SAC sided with the Canadian Union of Students (CUS) to call for the elimination of tuition fees. On the second point, SAC insisted that because the student "is a mature individual capable of governing himself [sic]" students should have an equal say with faculty in the governing of the university. ${ }^{51}$ The lack of this recognition on the part of the university administration had given rise to the demands for student power. Student power, according to a SAC brief to the Commission on University Government (CUG), was seeking to give students equality and respect; to assume a degree of control in shaping their lives; to participate in decision-making; to establish a sense of community; and to make major changes to the university, education, and relationships with others. ${ }^{52}$

The newly elected SAC leaders made the same appeal in regard to access to contraceptives. One of the first actions Tom Faulkner, the incoming SAC President, took in the spring of 1966 was to sketch out new areas of responsibility SAC could assume under his tenure. Faulkner suggested that SAC "must always be trying to do more for the student." Therefore, he proposed that the Education Commission, one of SAC's committees, must continue to promote its drama workshops, political affairs, and a music program. But it could also investigate organizing seminars on studying, note taking, exam preparation, and birth control and sex education. ${ }^{53}$ Faulkner's wish list for the Education Commission indicated the casualness with which seminars on birth control and sex education could be added to commonplace student concerns. It also spoke to the influence of other student groups that supported birth control and that expected SAC to take a leading role in the matter. The Student Democratic Union (SDU) developed an extensive action program for SAC. It included increased student aid, lower food prices, book discounts, greater student participation in university government, better course evaluation methods, and the provision of birth control information. "Since personal moral behaviour is the responsibility of the individual and not the state or the university," the program read,

the SDU will support the individual's right to birth control information. The SDU will ask the Health Service to make birth control information available to all who request it, and in the even

50 SAC, S. K., Untitled document on the history of SAC, 1975? p. 18.

51 UTA, A84-0019, Box 061, File: SAC University Government Commission, 19681969, "SAC Brief to the Commission on University Government," 10.

52 Ibid., 6.

53 UTA, A84-001, Box 061, File: SAC, University Government Commission 19671968, "Dear Council Member," by Tom Faulkner, March 9, 1966. 
that the Health Service fails to assume this responsibility, the SAC will undertake it. ${ }^{54}$

Faulkner's first year as SAC president coincided with the sixtieth anniversary of the Health Service and with Wodehouse's appointment as its full-time Director. Cognizant that Wodehouse had left private practice to take up the position, Ross lobbied hard for the additional money to cover Wodehouse's salary. In a confidential letter to U of T President Claude Bissell, Ross acknowledged that the Health Service was "now so important and, frankly, growingly expensive that I think it is just bad economy not to have a full-time Director.” Because the Health Service budget was already meagre, Ross recommended that most of the funds could come from monies allotted for student Convocation, thereby delaying the purchase of diploma covers for graduating students. Bissell agreed. $^{5}$

Wodehouse may never have known that his full-time salary had swung on such an innocuous bargain. But he was certainly well aware of the higher administration's frugality. Therefore in his annual report to the $\mathrm{U}$ of $\mathrm{T}$ President, Wodehouse celebrated the Health Service's accomplishments over the last sixty years. The Health Service, he noted, had benefited the entire university community. Its physicians, past and present, had teaching appointments at the Faculty of Medicine or were staff members of illustrious local hospitals such as St. Michael's, Sunnybrook, Women's College, and the Clarke Institute of Psychiatry. With the introduction of new provincial medical insurance plans, student demands on the Health Service were sure to multiply, more so than ever before. Wodehouse's strong emphasis on the rise in student visits was meant to signal to the university administration the need for a larger Health Service budget that would unite the Men's and Women's Divisions, consolidate other services scattered throughout campus, and expand the available facilities. ${ }^{56}$ Although he mentioned that in Toronto, "as in most other centres, there was increased student interest in sex education and contraception and prescription," he did not cite the growth of that interest as part of the rationale for more Health Service monies. Rather, his point of pride was that the interest had been anticipated, discussed, and dealt with. As proof, he reproduced verbatim the Advisory Committee's policy on contraceptive prescriptions. The policy, according

54 UTA, A84-0019, Box 061, File: SAC University Government Commission 19671968, Student Democratic Union, "A Programme of Action for the Students' Administrative Council," 1967? p. 2.

55 UTA, A75-0021, Box 041, File: Health Services, Letter from Robin Ross to Claude Bissell, April 21, 1966, and letter from Claude Bissell to Robin Ross, April 26, 1966.

56 UHS, Three-page document by G. E. Wodehouse, M.D., Director, appended to Minutes of the Advisory Committee to the University Health Service, Sept. 14, 1965. 
to Wodehouse, had made the position of the Health Service "more comfortable." ${ }^{57}$ He spoke much too soon.

\section{The Varsity Weighs In}

Shortly after the Second World War, the Varsity carried numerous stories about the need for a mental health clinic on campus that pressured the Health Service Advisory Committee to do its bit. ${ }^{58}$ Two decades later, this student newspaper became SAC's powerful ally in promoting students' access to birth control services. $U$ of $T$ students were first apprised of the pill's wonders in a Varsity article reprinted from the Dalhousie Review and published in the spring of 1965. Authored by Tony Bond, the piece was illustrated with a photo of oral contraceptives and captioned enticingly: "These little pills make by far the best method of contraception." Bond did not criticize university Health Services but Canada's archaic birth control laws. Despite the illegality of contraceptives, the pill was available. Abortions had merely gone underground. At the United Nations, Canada was forced to sit "like a Presbyterian prude" because it could not participate in debates about birth control. The situation was especially serious because of the possibility of a Third World population explosion. ${ }^{59}$

This popular argument held that many Third World countries were backward because their birth rate was out of control. By contrast, Canada had a population of a few million. Still, it was not a modern nation because its birth control laws were outdated. A reduction of the birth rate in India, Haiti and Puerto Rico was proof of modernity. In Canada, reform of the birth control laws would constitute the same. So too would a domestic population policy encouraging birth control among lowincome groups, "Indians," and "Eskimos." ${ }^{\circ 0}$ Although Bond asked the medical profession to do its bit to curb the birth rate, his population explosion argument stopped short of suggesting doctors at university Health Services prescribe oral contraception to single women students.

Over the next few years, the Varsity carried several reports, debates, articles, and letters about birth control. Abortion was the most contentious topic, generating fiercely opposing views. When Paul Macrae, a thirdyear sociology student, opined that the illegality of abortion was harmful to women, another student responded that Macrae's article was the product of a "confused mind." Reporting on other university Health Services from near and far was another major preoccupation. Varsity

\footnotetext{
57 Wodehouse, "The Director of the University Health Service," 218.

58 UHS, Minutes of the Advisory Committee to the University Health Service, April 11, 1946, 5.

59 Tony Bond, "Conception and Birth: Birth Control...a factual survey...Abortion," Varsity: Review, March 12, 1965, p. 1. My thanks to Catherine Gidney for this reference.

60 "Birth control laws backward: dean," Varsity, Dec.2, 1966, p. 17.
} 
readers learned, for example, that the head of the Health Service at the University of Western Ontario had denied prescribing birth control pills to single women students and that Berkeley University students in the United States had voted 4-1 in favour of the distribution of pills by their campus Health Service. ${ }^{61}$

In early 1967 the newspaper published a lengthy interview with a young, single, pill-taking student identified only as "Carol." One the one hand, her anonymity gave the lie to the decade's stereotype of sexual openness. On the other, it permitted her to be very forthcoming. Consequently, this interview was one of the few instances in which the opinion of a female student on oral contraception was highlighted so centrally in the Varsity. Carol recounted that when her girlfriend became pregnant she was forced into a shotgun marriage. Carol was determined not to meet the same fate. She and her boyfriend were having a "meaningful relationship" that necessarily included sexual intercourse. However, she did not want to get pregnant. She wanted a career but did not want to deny herself sex even if it did not lead to marriage. "I don't believe in the Doris Day movie world where the girl doesn't have any sex urges," Carol was quoted as saying. She insisted that it was more moral "to take the pills with no illusions, than to take chances believing in the chaste Doris Day world. You take the pills so your life, and the lives of a child and other people, won't be ruined." Carol said she did not go to the $\mathrm{U}$ of $\mathrm{T}$ Health Service because she was told that its doctors did not prescribe pills unless girls could prove they were getting married. It was unclear how she obtained this information. She decided to phone Planned Parenthood to get the name of a doctor who provided her with the pill. "I think this is an evasion of responsibility on the part of the Health Service," Carol concluded. Alongside Carol's interview was a quote from Wodehouse centred in a square box. It contained the very words that led an enraged Sayers to write to the Varsity:

For single girls...we feel that celibacy and avoidance is proper. We are, however, willing to provide information about the mechanics and emotional aspects of sex to any girl who asks us. If an unmarried girl is determined to get pills, and can show me what she is doing...we will put her in touch with a reputable doctor. That is the least we can do. ${ }^{62}$

The contrast between the young, single, female student and the veteran male Health Service Director was sharp and unmistakable. Carol appeared realistic, responsible, and adult. Wodehouse seemed ancient,

61 "Western denies birth control charges," Varsity, Jan. 13, 1967, p. 21, and "Berkeley votes 4 to 1 for the pill," Varsity, Jan. 16, 1967, p. 15.

62 "Birth Control Pills Lead to Sexual Responsibility: Co-Ed,” Varsity, Feb. 6, 1967, pp. 6-7. 
inadequate, and out of touch. At face value, Carol's testimony reflected the shift in the sexual mores that sanctioned premarital sex. At a deeper level, it signalled her desire for a sex life and a career. Both needs can be read as indicators of a burgeoning women's liberation consciousness. They may also be viewed as aspirations peculiar to a white, middle-class sense of entitlement to personal and professional fulfilment that an unintended pregnancy could potentially destroy. Precisely because campus Health Services were stingy with pill prescriptions, Carol and her peers began flooding family planning clinics that had originally been established to dispense contraceptives to poor, married women. As statefunded medical insurance became more accessible, this clientele gravitated toward private physician care, only to be replaced at family planning clinics by a population of ambitious and goal-directed single women university students requiring pills, not platitudes. ${ }^{63}$

Ambition and goal-directedness were characteristic of five other pillpopping single women students subsequently profiled in the Varsity. Like Carol, all five were granted anonymity, being identified only by a first name. Joan said she might be branded a feminist but liked sex and needed it. She found the diaphragm inadequate and was against abortion. She began taking the pill after a pregnancy scare, reasoning that she had to take her educational aims and her family into consideration. Lynne admitted to having sex with married and unmarried men. The pill ensured she would not get pregnant and "really mess up" her life. Mary was in love with another university student. Both felt it was normal to have sex before marriage but were opposed to abortion. With just one more year of school to complete, neither could afford to deal with an unwanted pregnancy. Ellen was having sex with boyfriend Burt but was not ready to marry until she graduated. She was, however, ready for "an adult relationship" that included rewarding, regular sexual activity. She thought that the pill should be made available to any woman who wanted it. Susan said she had been sleeping with Sam for several months. Sex was a natural outgrowth of their relationship. Because she too couldn't face the prospect of an abortion, or of "messing up" their lives with an unwanted pregnancy, she went on the pill. ${ }^{64}$

The interviews offered proof that premarital heterosexual intercourse was a fact of life on the $U$ of $T$ campus. They also indicated that the pill was the contraceptive preferred most often by single women students because it offered them a clean solution to the "mess" of an unintended pregnancy. Whether involved with one steady partner or with several men, single women students were willing to seek out contraceptive

63 Kathleen Belanger and Eleanor J. Bradley, "Two Groups of University Student Women: Sexual Activity and the Use of Contraception," JACHA 19, 5 (June 1971): 30712, and Marion G. Powell, "Changing profile of a family planning clinic," in Family Planning in Canada: A Source Book, ed. Ben Schlesinger (Toronto: University of Toronto Press, 1974), 196-98.

64 "The Pill: Five who do," Varsity, March 17, 1967, p. 7. 
protection with or without the assistance of the Health Service to safeguard their personal and professional gains. However, the interviews left unexplored, at least in print, the convenience the pill offered the men with whom these women were involved. Certainly, by the late 1960s, nascent feminist groups had begun to equate the sexual revolution with male heterosexual self-interest. The pill, some feminists contended, liberated women from the fear of an unintended pregnancy. Yet it also made more women available to more men for more of the same kind of sex. Locating the source of women's sexuality in the clitoris, not the vagina, many discounted the sexual revolution as a myth driven by male sexual pleasure for the purpose of female sexual exploitation. As some women active in the Canadian Student Union for Political Action stated succinctly: "Women are screwed; men do the screwing.",65

For its own part, SAC barrelled ahead, approving the formation of a birth control program committee to co-ordinate seminars at women's residences and to distribute information from local Planned Parenthood groups that contained the names of doctors who would supply contraceptives. Allowing that SAC had long been known for its "lethargy," the Varsity praised SAC's efforts as "encouraging." 66 The birth control program was a direct indictment of the Health Service. Faulkner acknowledged that the distribution of birth control information was technically illegal. But he asserted that the Health Service was reluctant to "give such information to anyone but married women." ${ }^{\prime 67}$ The SAC birth control committee soon ran into opposition. Laurel Limpus, the committee's head, was officially requested not to hold meetings with students in the women's residence for St. Michael's College, a Catholic bulwark on campus. Limpus explained that she wanted only to have a quiet discussion with interested students and to pass on the names of Planned Parenthood doctors if the students so requested. But the "general attitude," she complained, "seems to be that having sex is more damaging than a pregnancy." ${ }^{\circ 8}$ Faulkner also ended up on the hot seat. Shortly after SAC approved of the birth control committee's activities, Ontario Attorney General Arthur Wishart threatened to investigate. Faulkner reacted with defiance. He was quoted in the Varsity as saying: "there is

65 Judy Bernstein, Peggy Morton, Linda Seese, Myrna Wood, "Sisters, Brothers, Lovers...Listen..." in Women Unite! An Anthology of the Canadian Women's Movement (Toronto: Canadian Women's Educational Press, 1972), 35. For similar critiques in the United States, see Ruth Rosen, The World Split Open: How the Modern Women's Movement Changed America (New York: Penguin Books, 2001), 143-57.

66 "Page Four: Of birth control, draft dodgers and hippies," Varsity, Sept. 22, 1967, p. 4.

67 SAC, Second General Meeting of the Students' Administrative Council, Sept. 20, 1967, p. 11.

68 Sherry Brydson, "SAC birth-control efforts opposed," Varsity, Oct. 6, 1967, p. 1. 
a remote chance that I could go to jail over this, but it is very remote, and I'm prepared to risk it." 99

Precisely because of the publicity the Varsity continued to give the birth control issue, Wodehouse furnished Jack Sword, Acting President of the University of Toronto, with a copy of a letter he had sent to George Tatham, Dean of Students at Glendon College, York University. Wodehouse asserted that other than the Heath Service policy, there was no official university statement on birth control. "I feel it might be helpful," he wrote, therefore, to Sword, "if you had this at hand."70 Wodehouse acknowledged that the policy may be seen as indecisive, or as an interfering with parental responsibilities. He revealed that the Health Service was torn between its obligations to the patient, its position within the University and its "strong reservations about the propriety" of prescribing contraceptives to single women, especially if under age 21 and a ward of their families. He acknowledged that the Health Service held regular discussion groups with groups of women students in the women's residences on sex education and family life education. Health Service doctors also allowed engaged students to start taking the pill anywhere from two to five months before their wedding date. And when the examining physician found unmarried patients to be "stable, wellinformed and clear in their intentions," as was almost always the case, they could be referred to a gynaecologist or to the Toronto General Hospital where they would receive contraceptive advice and care. Using the vocabulary of infectious diseases, he asserted that many single, pillseeking patients had already established a sexual relationship with a man they planned to marry and to whom they had been sexually "exposed" for several months before their Health Service visit. Under such circumstances, he would prefer as a parent to know that students were "getting adequate help in avoiding pregnancy and its complications.",71

One of those complications was abortion. Upping the ante on its birth control coverage, the Varsity ran a story about a second-year student from an out-of-town university. "Sandy" had tried to get the pill, only to discover that she was already pregnant. A doctor she saw refused to perform an abortion or to pass along the name of a sympathetic physician who would. Sandy went to Toronto to meet up with two friends at U of T. After several frantic phone calls, one local abortionist was found. He refused to perform an abortion because he was under police surveillance. Another friend called with the name of a nurse but Sandy refused to have the procedure done by someone other than a doctor. In the end, a

69 "SAC draws government attention by backing birth control committee," Varsity, Sept. 22, 1967, p. 1.

70 UTA, A75-0021, Box 103, File: Health Services, letter to J. H. Sword from G.E. Wodehouse, Oct. 6, 1967.

71 Ibid., Health Services, letter to Professor George Tatham from G.E. Wodehouse, Oct. 6, 1967. 
distraught Sandy travelled to Montreal with her boyfriend to have an abortion for $\$ 200$ in a hospital. ${ }^{72}$

For both students and doctors at the Health Service, the issue of abortion was impossible to avoid. Faulkner identified himself as a virgin and therefore, the "most sexually naive point man" for birth control. Yet he later claimed he was motivated to push ahead with the SAC student birth control program because of accounts of illegal abortion. He had heard that young $U$ of $T$ women were becoming pregnant and "scraping themselves with coat hangers."73 Wodehouse's annual report to the University President for 1967-1968 admitted as much. Wodehouse acknowledged that there was a rash of unplanned pregnancies on campus. In some cases, the student's pregnancy led to marriage, in a few others to abortion. The Health Service refused to refer students seeking abortions to unauthorized abortionists. Because of the strict interpretation of an existing law that permitted abortion only in the case of a danger to a woman's life, 60 to 70 per cent of the Health Service's referrals were successful. ${ }^{74}$ Wodehouse openly expressed his frustration at two situations - when pregnant students would not or could not marry, and when, unable to access the therapeutic termination of a pregnancy in a local hospital, pregnant students went ahead with an illegal abortion in other cities. ${ }^{75}$

Movement across borders to procure an illegal abortion was quite common in the 1960s. Abortions were illegal in Canada. But under Section 5(2) of the Criminal Code, no person could be convicted in Canada for an offence committed outside the country. ${ }^{76}$ Canadian women who could afford to flocked to destinations like London and New York to procure an abortion. Japan was also on the abortion itinerary of Canadian women. It was even speculated in Parliament that Canadian girls took vacations in Europe so they could be aborted in Sweden. ${ }^{77}$ Dr. Davis recalled one Health Service patient, 12 weeks pregnant, who went to the United States for an abortion. "I was very worried about her," she said, "wondering if she would have someone with her and then coming back bouncing on a bus from Buffalo."78 Like "Sandy," women also travelled to Toronto seeking the services of underground abortionists. Dr. Smith remembered pronouncing three young women dead of

72 "What does a girl do if she's in the middle of the school year and suddenly discovers she's pregnant?” Varsity, March 6, 1968, pp. 6-7.

73 Personal telephone interview with Tom Faulkner, April 13, 2002.

74 Agi Lukacs, "Health Service Cuts Abortion Red Tape," Varsity, Feb. 3, 1971, p. 3.

75 G.E. Wodehouse, "The Director of the University Health Service," President's Report 1967-1968, 150.

76 Badgley, Caron, and Powell, Report of the Committee, 64.

77 Standing Committee on Health and Welfare, 9.

78 Personal telephone interview with Dr. Ruth Davis, May 16, 2002. 
complications from botched criminal abortions in the city. All had travelled from smaller towns to terminate their pregnancies. ${ }^{79}$

\section{Widening the Loophole on Pill Prescriptions}

In response to the abortion issue, the Advisory Committee decided on March 7, 1968, to widen the loophole in the Health Service's policy on prescription contraceptives. With Faulkner now sitting as one of the student representatives, the Advisory Committee reaffirmed the need for the Health Service Policy and its loophole. This time, however, the members agreed that "some circumstances arising in increasing numbers might justify a broadening of this phrase." The language was discrete. But there was no mistaking the intention. The loophole now made room for Health Service physicians to prescribe the pill on the spot to single students in the hope of preventing unplanned pregnancies and subsequent illegal abortions. Perhaps to reassure nervous administrators, colleagues, and parents, and to stem a possible flood of single students seeking the pill, the Advisory Committee confirmed that the Health Service would not prescribe "on demand." Such a practice "would not constitute good or adequate treatment of the individual." Importantly, signalling its cooperation with SAC, the Committee also advised that the Health Service and Faulkner could explore the development of a sex education program for students. ${ }^{80}$

The Health Service's more liberal public stance on pill prescriptions had a direct impact on student visits. Over the 1968-1969 academic year, the Women's Division of the Health Service reported that its gynaecological service had increased "by leaps and bounds." A total of twenty-nine cases had to be referred for obstetrical and gynaecological consultation, representing the third highest number of consultations after psychiatric and surgical cases. ${ }^{81}$ The shift on pill prescriptions had undoubtedly occurred because of student pressure. It may also have been motivated by the belief that the reform of the country's birth control legislation was at hand. Indeed, in 1969 Parliament passed a bill intended to take effect in August that decriminalized contraception and liberalized abortion. By this time, many Canadians had experienced a major change of opinion in regard to contraception. In 1952, 48 per cent of Canadians polled said the practice of birth control was not morally wrong. By 1965, that number registered at 66 per cent..$^{22}$ Catholics, the segment of the Canadian population expected to be most resistant to the liberalization of

79 Personal telephone interview with Dr. David Smith, May 9, 2002.

80 UHS, Minutes of the Advisory Committee to the University Health Service, March 7, 1968, pp. 1-2.

81 UHS, F.H. Stewart, “Women’s Division: Annual Report,” May 20, 1969.

82 Canadian Institute of Public Opinion, "An Increasing Number of People Favour Birth Control," Feb. 13, 1965. 
birth control on religious grounds, were also in agreement with rest of the country. In 1966, more than six in ten Catholics surveyed said that their Church would eventually approve of an artificial method of birth control such as the pill. The highest numbers recorded were in the mostly Catholic province of Quebec. ${ }^{83}$

When the papal encyclical Humanae Vitae categorized the pill as an artificial method of birth control that was, like any other contraceptive, forbidden to Catholics, 41 per cent of Canadian Catholics said they disagreed with the ban. ${ }^{84}$ On campus, the issue burned white hot in the writings of Fr. Gregory Baum. A professor at St. Michael's College, Baum declared that Catholics were no longer moved by traditional arguments of the intrinsic evil of contraception. To Baum, there was little difference between the rhythm method - approved by the Church - and contraceptives. The former imposed a barrier of time between egg and spermatozoan, the latter of space. Whether natural or artificial, birth control, according to Baum, permitted couples to develop a relationship that acknowledged the place of responsible parenthood and sexual desire in marriage. ${ }^{85}$

For Canadians, abortion remained a more contentious issue than contraception. In the mid-sixties, a majority of Canadians surveyed agreed that the legal reasons for an abortion - to save a woman's life should include the preservation of a woman's mental and physical health. ${ }^{86}$ The new law technically took these additional concerns into account. But the conditions under which a legal abortion was now permissible after 1969 proved extremely restrictive. Legal abortions were permitted only if a woman had a referral from her doctor to a hospital's therapeutic abortion committee (TAC). The TAC, consisting of three or more doctors (the doctor who referred the woman for an abortion could not sit on the TAC), had to rule that an abortion was necessary to preserve the woman's health. Hospitals were not obligated to strike TACs. Nowhere was there a consistent definition of what constituted health. Moreover, doctors could refuse to perform abortions; many remained divided over the morality of the procedure. ${ }^{87}$ As a result, the new law did not stop illegal abortion. Performed by medical and non-medical personnel or self-induced, illegal abortions were estimated at 100,000 a

83 Ibid., "Majority of People Feel Catholics Will Change Stand on Birth Control," July 6, 1966

84 Ibid., "Nearly Half Canada's Catholics Against Pope's Birth Control Ban," Dec. 14, 1968.

85 Gregory Baum, “Can the Church Change Her Position on Birth Control?” in Contraception and Holiness: The Catholic Predicament, ed. Thomas D. Roberts (New York: Herder and Herder, 1964), 311-44.

86 Canadian Institute of Public Opinion, "Canucks Want More Extended Reasons for Legal Abortion," Sept. 11, 1965.

87 Gerald Waring, "Report from Ottawa," Canadian Medical Association Journal (CMAJ) 98, 8 (Feb. 28, 1968): 419. 
year. ${ }^{88}$ Discontent over a law that neither prevented illegal abortions nor decreased maternal deaths from botched abortions led women involved in a nascent women's liberation movement to organize around the repeal of the abortion law. ${ }^{89}$

One consequence of the growth of the women's liberation movement meant that the issue of access to contraception and abortion came increasingly under the purview of feminist politics on campus. A newly founded group called Women's Liberation Movement (WLM), took action. In the summer of 1969, it set up a Birth Control Centre at U of T. Approximately 20 people a day came in to look at various contraceptive devices and pamphlets on birth control. The main source of information on birth control the WLM distributed was the Birth Control Handbook. ${ }^{90}$ Concerned with the problem of illegal abortion, a student birth control committee struck by the McGill Student Council published the Handbook in $1968 .{ }^{91}$ It provided details on a wide range of birth control devices and methods. In the case of an unwanted pregnancy, it also endorsed abortion performed by competent, medically trained doctors. The Handbook supported the right of all sexually active women, regardless of their class, marital status, or age, to reproductive freedom. The editors also denounced the population growth lobby, arguing that American imperialism and racism, not overpopulation, was the real cause of poverty in the Third World. ${ }^{92}$

The WLM's Birth Control Centre ordered 10,000 Handbooks for distribution to students from a tent pitched outside SAC headquarters during registration week in September, $1969 .{ }^{93}$ The Centre also made abortion referrals. Advertisements for the service were printed in the Varsity.$^{94}$ An estimated fifty women a week telephoned for help. Some of the callers were $\mathrm{U}$ of $\mathrm{T}$ students unsure about what to expect from their Health Service. But most were poor, non-university women, some of whom had recently immigrated to the country. Few understood whether abortion was legal or illegal. ${ }^{95}$ Harriet Kideckel, a U of T graduate who worked at the Centre, was concerned with the plight of poor students. She

88 Cope W. Schwenger, “Abortion in Canada as a Public Health Problem and as a Community Health Measure," Canadian Journal of Public Health $(C J P H)$ 64, 3 (May/June 1973): 223-29. For further information, see Badgley, Caron, and Powell, Report of the Committee, and Janine Brodie, Shelley A.M. Gavigan, and Jane Jenson, The Politics of Abortion (Toronto: Oxford University Press, 1992), 36-43.

89 Eleanor Wright Pelerine, Abortion in Canada (Toronto: New Press, 1972).

90 "Birth Control Spreading," Varsity, Sept. 22, 1969, p. 12.

91 McGill Student Union, Box 28, Minutes, Nov. 1967-June 1968, Jan. 18, 1968, pp. 2349-50.

92 Donna Cherniak, Allan Feingold, and the Students' Society of McGill University, eds., Birth Control Handbook (Montréal: Journal Offset Inc., Aug. 1970 [1968]).

93 "Birth Control Spreading," Varsity, Sept. 22, 1969, p. 12.

94 See, for example, "Toronto Women's Liberation Abortion Referral Service 5339006,” Varsity, March 15, 1971.

95 Agi Lukacs, "Health Service Cuts Abortion Red Tape,” Varsity, Feb. 3, 1971, p. 3. 
predicted that by the time the spring exams were over approximately 100 students would be pregnant and seeking abortions. Middle-class students could afford to raise the money to travel to the United States to have an abortion. But poor students could not. Their student loans and summer earnings would not be able to cover the costs. Kideckel blamed the Health Service for making it difficult for a single woman to obtain the pill. ${ }^{96}$ Despite Kideckel's claims, the Criminal Code reforms emboldened the Health Service to provide students with on-the-spot pill prescriptions and much more - so much so that those students who were still under their parents' medical insurance plan were not billed for certain services. The Health Service was concerned that parents would become aware of the sexually related nature of the problems for which their children were being treated..$^{97}$

\section{Contraception, Abortion and Venereal Disease}

For the Health Service, the post-1969 period was full of ironies, large and small. The publication of Barbara Seaman's best-selling book, The Doctor's Case Against the Pill (1969) generated widespread concern about the pill's negative side effects. Seaman provided frightening medical evidence that showed the pill was linked to both fatal and nonfatal complications. ${ }^{98}$ The ensuing furore over her findings led to Senate hearings in the United States in early 1970. The Canadian Medical Association (CMA) responded quickly, urging that the pill should not be withdrawn. Rather, it advised that each doctor had to weigh carefully the benefits of virtually 100 per cent effective contraception against possible side effects for each patient. For example, the pill was not to be recommended to those with a history of diabetes or thrombosis. ${ }^{99}$

News of the pill's negative side effects forced Wodehouse into a difficult position. As Health Service Director, he had taken student heat for a Health Service policy that, on the surface, had restricted pill prescriptions to students who were married or engaged. He now found himself defending the pill's safety while, simultaneously, rationalizing the Health Service's decision to prescribe oral contraceptives to his student clientele, whether married or single. Wodehouse turned to the Varsity, the very same newspaper that had denounced the Health Service for its timidity regarding pill prescriptions, to outline his defence of the

96 Harriet Kideckel, "Abortion now a fact of life...if you're rich," Varsity, Oct. 2, 1970, p. 3.

97 UHS, G.E. Wodehouse, “Advisory Committee to the University Health Service Director’s Interim Report,” Oct. 20, 1971, p. 2.

98 Barbara Seaman, The Doctors' Case Against the Pill: 25 ${ }^{\text {th }}$ Anniversary Edition (1969; Alameda, California: Hunter House, 1996).

99 "The Pill: Thousands of Canadian women have been needlessly upset," CMAJ 102, 3 (Feb. 14, 1970): 227. 
oral contraceptive. Using the CMA statement as a guide, Wodehouse announced that the Health Service would prescribe the pill to any student who requested it. However, she first had to pass a thorough medical examination. Any patient who did not, would be advised about other contraceptive methods. In effect, the Health Service's criterion for pill prescriptions was no longer the patient's moral suitability as designated by her marital status but her physiological fitness based on the outcome of her medical examination. ${ }^{100}$

The Health Service co-sponsored with SAC and the Department of Obstetrics and Gynaecology a series of evening educational sessions for students on the subjects of sexuality and reproduction, featuring experts from groups like Planned Parenthood. The Women's Division of the Health Service recorded large jumps in patient visits. Increasing numbers of students were coming in already pregnant. During the 1970-71 academic year, 165 students came to the Health Service suspecting pregnancy. All of them had had unprotected sexual intercourse. A total of 65 were pregnant. ${ }^{101}$ In the autumn of 1971, the Advisory Committee made a decision to formally review and update the Health Service policy on contraceptive prescription that had been formulated six years previously. The new policy reflected the difficult reality the Advisory Committee was now facing. In comparison, the dilemma surrounding pill prescriptions paled.

In an all-out effort to reduce unwanted pregnancy, the Health Service would offer "every facility within its power" to provide sex education, contraceptive prescription, and, where indicated, assistance in the termination of pregnancy. Never using the word "abortion," the new policy included two caveats. It stated plainly that the termination of pregnancy was "a most undesirable and inadequate" method of birth control and "no substitute for adequate contraception." Moreover, if the termination of pregnancy ran counter to the examining physician's "religious and moral convictions," the physician would inform the patient and refer her to another doctor who did not hold the same views. Fearing controversy, the Chair of U of T's Department of Obstetrics and Gynaecology urged that any public discussion of the new policy stress the importance of education and contraception over abortion. ${ }^{102}$

Overall, U of T student support for abortion in emergency and nonemergency situations had grown between 1968 and $1971 .{ }^{103}$ However, the Health Service proved more adept at helping students terminate

100 G.E. Wodehouse, "Health Service Director warns students about pill," Varsity, Feb. 11, 1970, p. 5.

101 G.E. Wodehouse, "The Director of the University Health Service," President's Report 1970-1971, 159.

102 UHS, Minutes of the Advisory Committee to the University Health Service, Nov. 10, 1971, p. 1.

103 Michael F. Barrett and Malcolm Fitz-Earle, "Student Opinion on Legalized Abortion at the University of Toronto,” CJPH 64, 3 (1973): 294-99. 
pregnancies than in preventing them. Doctors at the Health Service were able to tap into a vast network of former $\mathrm{U}$ of $\mathrm{T}$ students, colleagues, and professors who worked and taught at local hospitals like Women's College, Sunnybrook and Toronto General that performed abortions. In the 1971-72 academic year, 429 new patients came in for contraceptive advice and prescription. Another 173 young women thought they might be pregnant but only 66 were. Only four carried their pregnancies to term. Most obtained abortions. Almost all of the abortions were arranged by the Health Service and by U of T's teaching hospitals. Another fifteen patients were given morning-after pills. ${ }^{104}$

Neither the old nor the new policy could prevent another problem now facing sexually active students: venereal infection. Wodehouse apprised the President of $U$ of $T$ that the combination of sexual freedom and the pill had facilitated the spread of venereal disease in the student population. ${ }^{105}$ Although the general incidence was far below wartime highs, venereal disease was making a recurrence in the province. By the early 1970s, the highest incidences of reported cases of syphilis and gonorrhoea had been recorded in adult males. Yet young women on the pill, who were presumably free to engage in sex with multiple partners, were scapegoated for spreading infection. Asymptomatic women were believed to constitute a major public health threat. ${ }^{106}$ Between 1970 and 1971, the Health Service found that fourteen students tested positive for gonorrhoea, two for syphilis, and one for lymphogranuloma venereum. In four cases where females tested positive, they appeared symptom-free. On occasion, Health Service doctors discovered the existence of venereal infection while conducting the routine gynaecological exam required for a pill prescription. ${ }^{107}$

The Health Service was not willing to blame women entirely for the rise in sexually transmitted disease. Wodehouse suggested that because of the availability of the pill, men were no longer wearing condoms. He argued that in sexual relationships occurring outside of marriage, men should wear condoms regardless of whether or not their partner was on the pill. Women should insist that their partners do the same. ${ }^{108} \mathrm{He}$ complained, as well, that widespread pill use had led students to believe that contraception was solely a woman's responsibility. Basing his

104 G.E. Wodehouse, "The Director of the University Health Service," President's Report 1971-1972, 166.

105 Ibid., President's Report 1968-1969, 163.

106 "VD Forecasts," Macleans, May 1965, p. 2; Barrett, "Sexual Experience," 368; Sydney Katz, "Youth and VD: Why must we still be worried?" Quest: Canada's Magazine for Parents, April 1967, pp. 9-10; C. Devadason, "Those Social Diseases," Canadian Welfare 50 (July-Aug. 1974): 14; Ontario Ministry of Health, Teaching Kit: Sexually Transmitted Diseases, A Community Problem, 1973.

107 G.E. Wodehouse, "The Director of the University Health Service," President's Report, 1970-1971, 159.

108 G.E. Wodehouse, "Health Service Director warns students about pill," Varsity, Feb. 11, 1970, p. 5. 
conclusion on the women students flowing into the Women's Division of the Health Service, Wodehouse indicated clearly that because both males and females produced a pregnancy, "it may be timely to remind the male participants that they too have a responsibility for producing an unwanted life." ${ }^{09}$ Finally, he deemed university students to be astonishingly ignorant about sexual physiology, venereal infection, and contraception. Lamenting to the $U$ of $T$ President that students arrived at the University of Toronto without "any real knowledge" of these matters, he called for the improvement of sex education for youths. ${ }^{110}$

THIS PRELIMINARY CASE study demonstrates that during the so-called sexual revolution of the 1960s, the pill was not readily available to young, white, single women. Despite their privileges of race and class, many of these women had difficulty getting access to the pill on the $U$ of $T$ campus because of the refusal or reluctance of the university's Health Service to prescribe it. While U of T students and the Health Service staff occasionally worked together for student access to birth control services, male and female student pressure on the Health Service was a significant factor in promoting single women students' access to the pill. The relationship of male and female students to the Health Service was grounded in student expectations of sexual freedom unmarred by the threat of an unwanted pregnancy and was also coloured by the Health Service's attempts to negotiate those expectations within the moral, legal, and administrative restrictions at $\mathrm{U}$ of $\mathrm{T}$. The result was a complex dynamic marked by conflict and collusion.

Personal interviews with individuals who were $\mathrm{U}$ of $\mathrm{T}$ students or Health Service physicians or family planning clinic staff during this time period will undoubtedly broaden this particular case study. ${ }^{111}$ Nevertheless, this preliminary account of the impact of the pill on the $U$ of $\mathrm{T}$ campus points to the need for further research in at least three of the following areas. First, it opens up for assessment the various ways in which male and female student sexualities have been regulated, and continue to be regulated, in institutions of higher education. Second, it encourages the study of the relationship between the political and sexual activism of students. Finally, because this case study reveals that male and female students challenged the structural surveillance of women's bodies before feminists began organizing over such issues, it calls for a more nuanced understanding of the second-wave feminist push for reproductive rights. In sum, this case study raises the questions: how and

109 G.E. Wodehouse, "The Director of the University Health Service," President's Report 1971-1972, 166.

110 Ibid., President's Report 1970-1971, 159.

111 I have received Social Sciences and Humanities Research Council of Canada funding to expand upon this case study. 
when did a feminist issue of access to birth control services become a student matter? And, when and how did this student matter become a feminist issue? 